\title{
Cloud Computing - Emerging Technology for Computational Services
}

\author{
Dan-Cristian CEARNĂU \\ The Bucharest University of Economic Studies, Bucharest, Romania \\ dan.cearnau@gmail.com
}

The evolution of the Internet, the web development, the complexity of Internet businesses, as well as the volume of data and concurrent application users have determined IT\&C specialists to design client/server applications on multiple layers, and on some cases even distributed solutions. The expansion of the Internet Service Providers networks and the accessibility of the Internet services have greatly increased the number of users that are using the Internet. This meant that new markets were opened for building new Internet businesses that rapidly grew in popularity. Because of the scaling issues generated by the large number of new users that are using Internet services, the IT\&C specialists have developed solutions to share resources between companies in order to reduce operational costs. By scaling down internal resources and migrating their applications to cloud computing services, companies are cutting-down costs, increasing availability of their applications and increasing their security.

Keywords: Cloud Computing, Cloud Computing architecture, cloud computing models, Big Data, IoT

\section{Introduction}

The spread of the Internet helped the globalization effort of both companies as well as governments and NGOs. Using the Internet, large, global organizations can be easily managed, even if they are scattered around the globe, on multiple timezones, cultures and languages. The Internet is the largest global market for companies, is free to access, uncensored (in most countries) and generally accepted by consumers, thus opening new business models and revenue streams.

As the usage of these new Internet businesses started to grow, they began to store and manage large volume of data, making this process expensive and dangerous as they become a target for hackers.

IT\&C specialists have started to look for new solutions to traditional client/server side architectures, and new ways to distribute data and applications across multiple regions. Because of the expansion of global businesses, it means that companies need to server customers from all around the world, and try to provide them with the same quality of services. This means building and managing new datacenters, improving the latency and bandwith of their applications and sharding data in order to prevent leaks and attacks from hackers.

The rapid and partially unespected growth of the Internet, created a lack of available resources for companies to use in order to expand their services. The high-demand for Internet solutions and low-availability of the hardware resources drastically increased the expenses and urged for a solution to share data centers between companies.

The evolution of the cloud computing evolved in several steps: Cluster Computing (1994), Grid Computing (1998), Cloud Computing (2000s). The Cloud Computing rapidly evolved affecting the new wave of applications and tools that helped bring the Internet services mainstream.

\section{The definition of Cloud Computing}

As the Cloud Computing concept grew in popularity, IT\&C specialists started to describe its most distinctive features. Robert L. Grossman noted that "Cloud computing doesn't yet have a standard definition, but a good working description of it is to say that clouds, or clusters of distributed computers, provide on-demand resources and services over a network, usually the Internet, with the scale and reliability of a data center." [2]. In 2011, Barrie Sosinsky defined Cloud 
Computing as "applications and services that are executed on a distributed network and using virtualization techniques that can be accesses by using the Internet". [3].

Collier \& Shahan wrote in 2015 that the Cloud Computing technology "insures transparency of the phisycal resources and their configuration, the final users having the perception that the resources that they have are theoretically unlimited" [4].

Features of the Cloud Computing have been identifier by specialists as the following [5]:

- Scalable - The number of users that can concurrently access the service given a certain quality and a reasonable cost.

- Ability - The capacity to allocate resources in a timely manner.

- Platform - To manage the services, billing, user management, etc.

The security, integrity and auto-scalability of the data was meant to assure the trust in the new technology. The flexibility of the services as well as the reducing of one-time costs for the deployment of new applications grew the interest of decision factors players in large companies to switch their architecture to cloud computing.

Both companies and governments have shown interest in adopting Cloud Computing technology in their activities, as presented in the cloud computing section from the national strategy. [6]. This strategy defines a series of European and national guidance for using cloud computing resources. This is considered to be very important by the IT\&C specialists for the development of all economic, social and cultural areas.

The importance shown to his industry is reflected in a study made in 2012 by the International Data Corporation, which shows that a direct investment made into Cloud
Computing of 45 bilion euros, will have an impact on the gross domestic product of around 957 bilion euros [7]. Cloud Computing represents a modern alternative on the traditional application architecture and will have a major impact on how businesses will be run in the future.

The theoretically unlimited and affordable resources available to service providers creates new opportunities for businesses to create partnerships and provide new services for consumers. Sharing and migrating user data between businesses enables them to create new revenue streams, new business models and provide cross-sells to consumers.

\section{Cloud Computing. Architecture.}

The Cloud Computing tehnology works by "renting" the physical resources that belong to a Client Service Provider (CSP). A CSP shares the same resources with multiple clients, and the security and isolation is made on multiple levels: network level, virtual machine level and application level. Since sharing the same hardware machine poses security risks, advanced virtualization tools and management consoles are used by the Client Service Provide to provide the service consumers (figure 1).

The main advantages of using Cloud Computing over traditional technologies is the increased reliability and quality. The network infrastructure as well as the virtal machines can be configured to automatically scale up in order to provide the best performances for the application as well as to scale down in order to cut down costs. The concept of flexible cloud means that application have access to theoretically unlimited resources, and they access this vast computing power only when it's needed. 


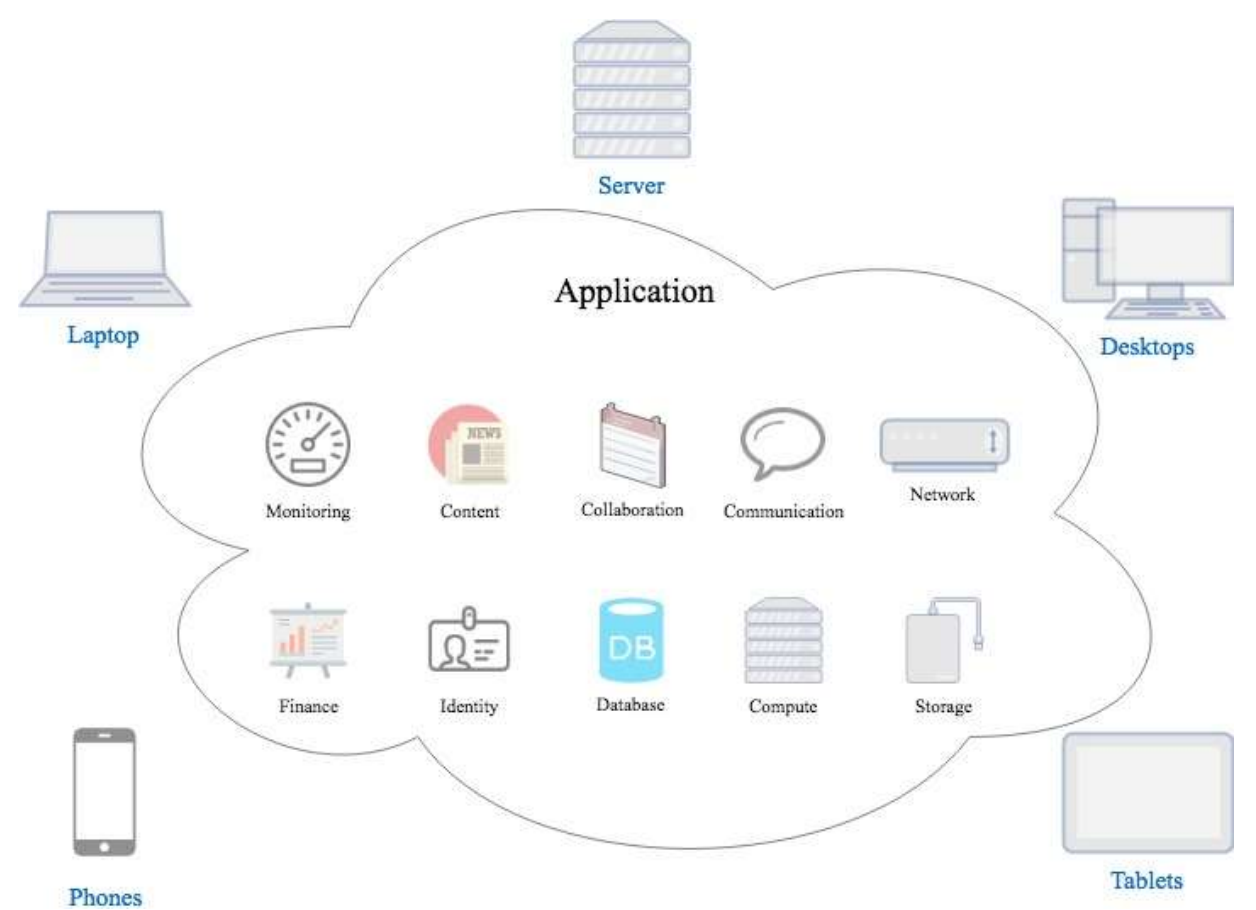

Fig. 1. Conceptual Cloud Computing diagram

Source: https://ro.wikipedia.org/wiki/Cloud_computing\#mediaviewer/File:Cloud_computing.svg[11]

The Cloud Computing technology refers to "storing, processing and using the data on remote systems accesses through the Internet" [9]. This means that consumers can access entensive resources without making expensive investments in infrastructure or specialized hardware. From a financial standpoint, the subscription payment model is also more flexible to companies that don't have the cash-flow to make investment in data centers (figure 2).
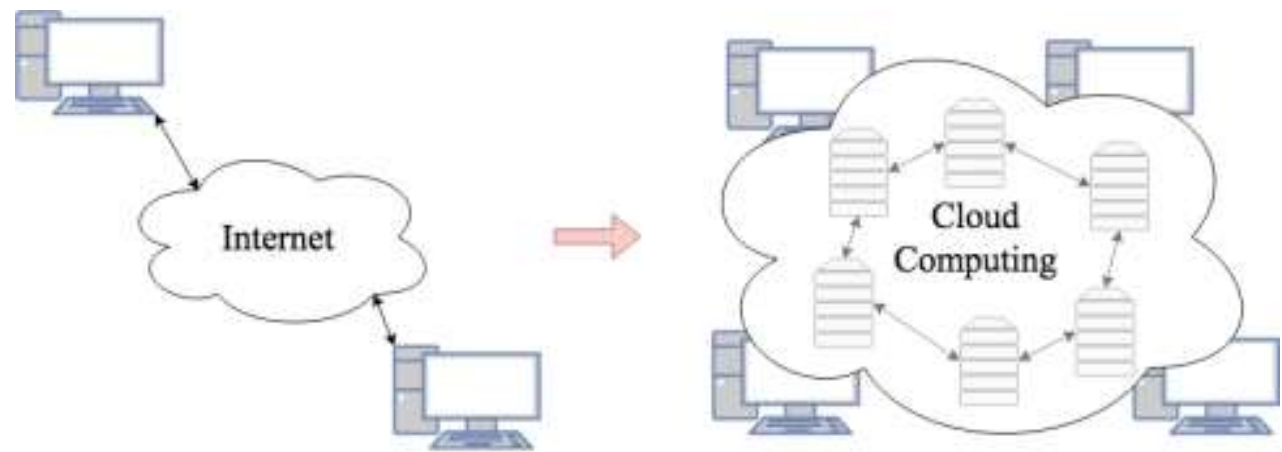

Fig. 2. Cloud computing architecture [10]

Source: http://andrei.clubcisco.ro/cursuri/f/f-sym/5master/aac-cc/2_Cloud_Computing.pdf

\section{Cloud Computing models}

There are 4 Cloud Computing models:

a). Private Cloud, the resouces are optimized and the IT infrastructure is used by a single corporation and it can be managed by the respective company or can be outsourced to a different company" [12]. Some of the companies that use Private Clouds are: IBM, HP, Microsoft, etc. b). Public Cloud, the IT infrastructure is owned and managed by a CSP (Client Service Provider) and is made available to the public through the Internet. The segregation and security of the data is maintened by the Cloud Infrastructure company, that also offers advanced management and billing tools to it's clients. Some of the most popular platforms for Cloud Computing services are: Windows 
Azure Platform (Microsoft), AWS (Amazon), Google Cloud, etc.

c). Hybrid Cloud, a combination of the two models, in which, the "IT infrastructure is composed of both the private and public Clouds, used as a whole and that used the same technology" [12]. This technology is used when applications have both public and internal usage and there is a need to a secure layer for protecting company data. d). Community Cloud, the "IT infrastructure is owned and managed by one of the community organizations" [12]. Since most of the Internet is built on open-source software (Apache, etc), large communities that build Cloud Computing solutions have grown to offer services to it's respective community.

The main advances of the Cloud Computing technology or traditional architecture are presented by Mihail Dumitrache (table 1).

Table 1. Cloud computing vs. traditional - advantages

\begin{tabular}{|l|l|}
\hline \multicolumn{1}{|c|}{ Traditional architecture } & \multicolumn{1}{c|}{ Cloud Computing } \\
\hline $\begin{array}{l}\text { Each company owns and maintains it's IT } \\
\text { infrastructure. }\end{array}$ & $\begin{array}{l}\text { The infrastructure is shared and used at it's maximum } \\
\text { load by multiple users. }\end{array}$ \\
\hline The systems are eterogeneous and complex. & $\begin{array}{l}\text { The service provided to customers are managed, } \\
\text { simplified and easy to use. }\end{array}$ \\
\hline $\begin{array}{l}\text { The company that uses the resources also manages } \\
\text { the infrastructure. }\end{array}$ & $\begin{array}{l}\text { The infrastructure is virtualized and managed by } \\
\text { specialists. }\end{array}$ \\
\hline $\begin{array}{l}\text { The technical support for running the system is } \\
\text { maintained in-house by the company, thus making } \\
\text { high-level support expensive. }\end{array}$ & $\begin{array}{l}\text { High-availability support for managing the cloud } \\
\text { solutions. }\end{array}$ \\
\hline $\begin{array}{l}\text { High costs for investing in data centers, and high } \\
\text { maintenance and utility (electricity) costs. }\end{array}$ & $\begin{array}{l}\text { Reduce costs by cutting down unused hardware in } \\
\text { data centers. }\end{array}$ \\
\hline $\begin{array}{l}\text { Source: Mihail Dumitrache, Cloud Computing - O nouă etapă in dezvoltarea Internetului, Revista Română de Informatică şi } \\
\text { Automatică, vol. 24, nr. 4, 2014, http://www.rria.ici.ro [9] }\end{array}$
\end{tabular}

As the Cloud Computing usage grew, it was necessary to create organizations that monitor and regulate the industry.

- Cloud Security Alliance (CSA), maintains the delivery of efficient solutions for managing the security of Cloud Computing infrastructure

- ISACA, independent association that develops and expand the IT infrastructure at a global level.

- Naţional Institute of Standards and Technology (NIST), federal agency that promotes the innovation and competitivity and maintains the security of the data.

- Article 29 Working Party - European Comision, working group since 24 october 1995 made on the bases of Directive 95/46/CE of the European Parlament and European Council. It acts as a guardian on the protection of personal data.

- European Cloud Partnership (ECP) organization that insures the development of common digital markets for Cloud Computing services in Europe.
There are multiple regulations on both European, US and global level to insure the security and availability of Cloud Computing services.

Besides the big US Cloud Providers that provide services at a global level, European countries have developed their own Cloud Computing services: G-Cloud in UK, Andromede in France, Trusted Cloud in Germany. At a European level, a unic access point to a large volume of data managed by European Union agencies was developed. The project called "European Union Open Data" [26] has the scope to provide free and easy access to data. The project is similar to the US project called Open Data that provides the same services at a federal level.

\section{Tools pentru Cloud Computing}

IT\&C companies specialized in research of distributed applications have made great innovations to make the Cloud Computing efficient and easily to be used by both companies and individuals. Cloud Service 
Providers developed complex tools to manage the shared resources and provide customers with a one-click deployment interface that hides all the complex virtualization technologies and presents its resources as "theoretically unlimited".

National Institute of Standards and Technology (NIST) developed 3 "service categories":

IaaS (Infrastructure as a Service) is a service that respects the characteritcs of the Cloud Computing NIST [13] and states that a company rents the IT infrastructure for its products and clients. The infrastructure is usually composed of virtual machines that are access remote, thus replacing the traditional IT infrastructure found in most companies. The Cloud Service Provider manages the hardware and maintains the security of the system.

In this structure, the operating systems, applications and content is managed by the service consumer: [14]. Example of IaaS services: Amazon Web Service (AWS), Google Compute Engine (GCE), Rackspace Open Cloud, IBM SmartCloud Enterprise, HP Enterprise Converged Infrastructure [9].

PaaS (Platform as a Service) is a system in which the Cloud Service Provider manages all the infrastructure, as well as the operating systems that run the applications. PaaS is easily to manage by consumers that IaaS since most of set set-up and maintenance is done by the provider.

SaaS (Software as a Service) is a service in which a provider offers to end-consumers subscription based applications. The applications are hosted, maintained and secured by the provider on it's own hardware resources. The types of applications that have migrated to SaaS model in the past year are: Enterprise Resource Planning (ERC) [15], Customer Relationship Management (CRM), Project Management, Human Resource Management (HR) [16], etc. Large IT companies have developed SaaS solutions that replace traditional applications such as: Microsoft Office 365, Google Docs, Zoho Office, Salesforce, Citrix GoToMeeting, Cisco WebEx, etc.

\section{Distributed Enterprise applications. Developing the Cloud Computing Infrastructure}

All types of computational resources are important within an organization for the performance of a custom-made software product, for processing and archiving data for future processing, for the security of data collections and for the speed of response the information system. All this has prompted major IT\&C companies to look for alternative technologies to deliver increasingly diversified and complex applications, solutions that meets the performance and security requirements for the customers with the lowest costs for them.

In the last instance, the technologies for designing and implementing client/server applications and cloud-computing as a highly efficient infrastructure solution managed by a specialized cloud provider have emerged.

With the emergence and development of Internet, Web programming, client/servertype applications that are running on the Internet and support the computer network have emerged and expanded. Their development, but especially the complexity and diversity of business models, as well as the large volume of possible simultaneous clients of these applications, have led IT \& C specialists to design client/server applications on 2, 3 or more layers and to introduce, more and more often, dedicated data and/or application servers. Their development and expansion has led to the emergence and then rapid development of distributed applications. Distributed Enterprise applications are therefore programs of an organization installed in a shared environment consisting of multiple computers communicating over a network with access to distributed databases The major IT companies are now looking for new, better-performing solutions for integrating IoT objects into distributed Enterprise applications using Cloud Computing and Big Data technologies as well as mobile devices for distributed data processing and storage at maximum security, high-speed response, storage capacities as 
large as possible, with the provision of a costeffective infrastructure.

The increased diversity of data sources across the organization, the growing volume, the quality and accuracy of the data to be integrated and then the increasingly complex processing, extraction and visualization represent some of the current features and requirements of the new IT \& $\mathrm{C}$ solutions in this area.

"The combination of PaaS and private cloud technologies merged into SOA architectures that enable companies to deliver information services is particularly important in streamlining distribution logistics, maintenance and support for enterprise applications" both domestic consumers and customers of the company or business partners " [18].

Valerică Greavu-Șerban centralized the most popular PaaS providers and their main features: [8] (table 2).

Table 2. Major PaaS providers

\begin{tabular}{|c|c|c|c|}
\hline Provider & $\begin{array}{c}\text { PaaS } \\
\text { Service }\end{array}$ & Programming languages and databases & Website \\
\hline Amazon & $\begin{array}{c}\text { Amazon Web } \\
\text { Services }\end{array}$ & $\begin{array}{ll}\text { - Java, .NET, .PHP, Node.js, Python, Ruby } \\
\text { - } \quad \text { MySQL, Oracle, SQL Server, PostgreSQL }\end{array}$ & aws.amazon.com \\
\hline Microsoft & Azure & $\begin{array}{l}\text { - Java, .NET, .PHP, Node.js, Python, Ruby } \\
\text { - } \quad \text { MySQL, MongoLab, DocumentDB, SQL Server, } \\
\text { PostgreSQL }\end{array}$ & portal.azure.com \\
\hline IBM & Bluemix & $\begin{array}{l}\text { - Java, Node.js, Ruby } \\
\text { - } \quad \text { SQL Server, JSON DB, MongoDB, Mysql, } \\
\text { PostgreSQL }\end{array}$ & bluemix.net \\
\hline Red Hat & Openshift & $\begin{array}{l}\text { - Java, Python, Ruby, Node.js, Perl } \\
\text { - MongDB, MySQL, PostgreSQL } \\
\end{array}$ & openshift.com \\
\hline Google & App Engine & $\begin{array}{l}\text { - } \text { Python, Java, PHP, Go } \\
\text { - } \text { CloudSQL (MySQL) } \\
\end{array}$ & $\begin{array}{l}\text { cloud.google.com } \\
\text { /appengine }\end{array}$ \\
\hline CloudBees & Jenkins & $\begin{array}{l}\text { - Java, Ruby } \\
\text { - MySQL }\end{array}$ & cloudbees.com \\
\hline Engine Yard & Engine Yard & $\begin{array}{ll}\text { - } & \text { PHP, Ruby, Node.JS } \\
\text { - } & \text { MySQL, PostgreSQL, Redis } \\
\end{array}$ & engineyard.com \\
\hline Salesforce & Heroku & $\begin{array}{l}\text { - } \text { Ruby, Node.JS, Python, Java, PHP } \\
\text { - } \text { PostgreSQL, Redis }\end{array}$ & heroku.com \\
\hline
\end{tabular}

Source: Valerică Greavu-Șerban, Cloud Computing. Caracteristici și modele, Colecția Cercetare avansată postdoctorală în științe economice, Editura ASE București, 2015, ISBN 978-606-505-982-5, pg 55[8]

It can be seen from the list of supported programming languages the orientation of the specialized companies to the web applications, but also to the solutions for mobile devices, which have lately experienced a very rapid expansion and expansion.

It is known that the extremely rapid development of distributed Enterprise applications over the last period is closely related to the way of communication between applications or their components. The most common distributed architecture is today the Web Application Architecture. A number of IT \& C companies are trying to find new, more efficient, less costly, and more reliable solutions for these architectures. As Microsoft builds his own web applications based on DCOM and ActiveX, Corba and Java are winning group by providing an architecture that links the web-products to objects [19].

Distributed applications are designed and developed based on the requirements of endusers (target group) and therefore must meet a number of specific features such as:

- have a hierarchical permissions system to ensure application security, while accessing and confidentiality data;

- the interface of the application is intuitive, easy to understand, to use visual elements known as shape and naming from common applications; 
- the internal references of the application are intuitive and the paths for accessing the desired information are short and fast [20].

- Practically, the design and deployment of distributed applications that today integrates Cloud Computing, Big Data and IoT performance technologies, and possibly mobile devices, must take account of, meet and streamline the requirements of all parties involved:

- information service providers that provide the infrastructure with maximum efficiency and security, software applications or high performance, accurate software, integrated electronic devices with the lowest cost, Internet connection and assured maintenance services.

- customers or beneficiaries of information services, organizations outsourcing most of IT \& $\mathrm{C}$ activities, using, on a monthly or yearly basis, the infrastructure and computational resources made available by companies specialized in such services. Much lower costs are expected for access to these services, compared to the cost of having the proper infrastructure of the company, the development of software products with their own strengths, maintenance and development, storage and archiving of larger volumes of data.

- end-users, who need to be better trained to understand and use correctly and fully all the facilities of distributed applications, information services they have access to, and modern IoT tools that they encounter more and more often.

\section{Conclusions}

At present, business, social, education, administration, health, culture, etc., virtually everything that surrounds us, awaits IT and communication solutions to automate all activities, devices and devices used in the production, services and current actions of organizations , citizens, the environment, and research in various fields. Expectations are high and are a great and varied challenge for both IT \& C specialists and large and small companies working in this area.

Practically, cloud computing radically changes the way companies are using their IT applications, but also the way in which information services are accessed by customers or users. We are basically talking about another way of organizing and delivering information services, a new, modern one. That is why we can appreciate that the provider of such services, the companies that mediate the distribution of cloud services, are doing (practically) for themselves a new business model that can bring them beautiful benefits.

Practice has proven, and specialists have verified that cloud computing architectures today enable more efficient use of company resources and a better service delivery mechanism for users [5].

The extremely rapid evolution and changes made by cloud computing both in the business environment and in the evolution of other information and communication technologies make it possible for specialists in the field to be reserved for their description in the future. However, Sosinsky predicts that in the future IT \& C will suffer a series of changes in functioning and development. Thus, the author believes that the applications we use today will be completely replaced by the applications offered in the cloud [3].

Easy access to the Internet, the continued development of cloud computing technology that provides users with easy access to computational resources and services, drives companies to change the way they work and organizes work, replacing the traditional office, the workplace in the company remote work, teleworking [23], thus benefiting from a number of substantial benefits in terms of both the cost and the working climate.

Cloud computing has necessitated and has stimulated the emergence and development of tools to store and process larger volumes of archived data in computerized organizations. Thus, Big Data refers to tools, processes and procedures that allow organizations to create, manipulate and manage large data sets and larger data storage facilities. We are talking 
about NoSQL databases, which are nonrelational databases [21], and thus become the core technology for Big Data.

To this is added today a new concept, "Internet of Things - IoT" (Internet of Things) or Internet of Everything, published in 1999, which defines "a network of objects incorporating electronic circuits that allow communication through the existing infrastructure) wireless or cable, for the purpose of remote monitoring or control "[22]. By interconnecting devices to IT \& C infrastructure, automation is being carried out in a number of areas, enabling the design and development of advanced software products. A successful area of use of IoT tools is expected to be that of household electricity consumers [17], tracking and quality control tools [24], complex integrated IT applications requiring current access to infrastructure performance at low or affordable cost for faster execution, security and data protection. Researchers in the field believe that cloud computing services now allow easier access and lower cost to customers or users of computing resources, stimulate the expansion of computerization or automation of organizations, and thus become "real incubators for new applications", large consuming resources and computational services [8].

Business research, specialty firms, today join major software companies that are doing their own high-level research in the field to deliver better performance solutions for both cloud computing and customer service providers and users. IBM, for example, proposes a new field of research, "cognitive computing" [25], which is based on cloud platforms and involves the use of computer power for assisting decision-making processes in various organizations.

The cumulative efforts of all stakeholders will rapidly change both the features of today's IT applications and the way that customers or users can access computing resources of all kinds (hardware, software, memory), but they will also generate other issues that specialists will be challenged to provide solutions such as data security, data reliability and results, reduced access time, shared access cost to computational resources, etc.

\section{Bibliography}

[1] Vicat-Blanc, P., Soudan, S., Guillier, R., \& Goglin, B., Computing Networks from cluster to cloud computing. Hoboken, NJ, USA: John Wiley \& Sons, Inc., 2011

[2] Grossman, R. L., The case for cloud computing. IT professional, 11(2), 2009, 23-27.

[3] Sosinsky, B., Cloud Computing Bible. Indianapolis, USA: Wiley Publishing, Inc., 2011

[4] Collier, M., \& Shahan, R., Fundamentals of Azure. Microsoft Azure Essentials. Redmond, Washington, USA: Microsoft Press, 2015

[5] Sullivan, D. (2010). The Definitive Guide to Cloud Computing. http://www.realtimepublishers.com/: Realtime Publishers

[6] Strategia Națională privind Agenda Digitală pentru România, Ministerul pentru Societatea Informațională, 2014

[7] Quantitative Estimates of the Demand for Cloud Computing in Europe and the Likely Barriers to Take-up IDC (2012).

[8] Valerică Greavu-Șerban, Cloud Computing. Caracteristici şi modele, Colecția Cercetare avansată postdoctorală în științe economice, Editura ASE București, 2015, ISBN 978-606-505-9825

[9] Mihail Dumitrache, Cloud Computing - O nouă etapă în dezvoltarea Internetului, Revista Română de Informatică şi Automatică, vol. 24, nr. 4, 2014, http://www.rria.ici.ro

[10] http://andrei.clubcisco.ro/cursuri/f/fsym/5master/aaccc/2_Cloud_Computing.pdf

[11]

https://ro.wikipedia.org/wiki/Cloud_com puting\#mediaviewer/File:Cloud_computi ng.svg

[12] Rețele de calculatoare, curs, UPB, Facultatea de Transporturi, 2017, http://tet.pub.ro/pages/RC/Retele\%20de \%20Calculatoare\%20-\%20Curs.pdf 
[13] NIST (National Institute of Standards and Technology)

[14] GHID Securitatea în Cloud - Asociaţia Naţională pentru Securitatea Sistemelor Informatice, http://www.certro.eu/files/doc/775_20131030091057011 764400_X.pdf

[15] Nicoleta Luminita Carutasu, George Carutasu, Cloud ERP implementation, FAIMA Business \& Management Journal, 2016/3, volume 4, Issue 1, pg 31-43

[16] Bogdan Ghilic-Micu, Marian Stoica, Cristian Răzvan Uscatu, Cloud Computing and Agile Organization Development, Informatica Economică, vol. 18 , no. $4 / 2014$

[17] Stănică, Justina Lavinia; Căruțașu, George; Pîrjan, Alexandru; Coculescu, Cristina, Iot Cloud Solution for Efficient Electricity Consumption, Journal of Information Systems \& Operations Management, May2018, Vol. 12 Issue 1, p45-57

[18] Zhe, Z., \& Xu, J. (2014). Design and Implementation Logistics Cloud Platform Based on SOA. Applied Mechanics and Materials, 775-780

[19] Carmen Stanciu, Tehnologii pentru aplicatii distribuite pe Internet, Revista Informatica Economica, nr. 9/1999
[20] Gabriel Eugen Garais, Evaluarea proceselor de mentenanţă a aplicaţiilor distribuite, Teza de doctorat, ASE, Bucuresti, 2011

[21] Mc Creary, D.; Kelly, D. A., Making Sense of NoSQL: A guide for managers and the rest of us, Manning, 2014, ISBN13: 978-1617291074, ISBN-10: 1617291072.

[22] Boscoianu, Elena-Corina, Popa D. Dragoș, Popa, Dragoș (2016), , Buletinul AGIR http://www.agir.ro/buletine/2673.pdf

[23] B Ghilic-Micu, M Stoica, A redefinition of telework through cloud computingtelework 2. 0, Jurnal Вісник Киівського національного університету ім. Тараса Шевченка. Серія: Економіка, 2016, nr. 11 (188)

[24] Bogdan Ghilic-Micu, Marinela Mircea, Marian Stoica, QAaaS in a Cloud IoT Ecosystem, Bucharest, Romania, Informatica Economică vol. 21, no. $4 / 20175$

[25]

http://www.ibm.com/developerworks/cog nitive/

[26] Portalul de date deschise al Uniunii Europene, http://opendata.europa.eu/ro/data/

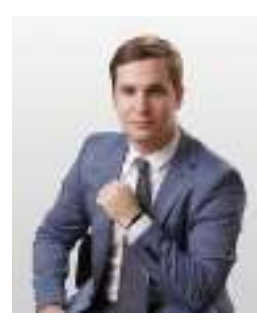

Dan-Cristian CEARNĂU is an experienced entrepreneur in Information Technology, owning a full stack development company. Dan has a background in advising, consulting and development of IT products is diverse, ranging from individuals starting their own companies to larger organizations looking for products that enhance their effectiveness. Starting from defining the concept and functionalities, defining the architecture and working towards an MVP. Also, he follows a doctoral program at the Bucharest University of Economic Studies, within the Doctoral School of Economic Informatics. 